\title{
Service-Learning in a Professional Discipline: Exploring Reflections of Aviation Science Students
}

\section{Stephen Belt}

Saint Louis University, USA

Leah Sweetman

Saint Louis University, USA 


\section{Service-Learning in a Professional Discipline: Exploring Reflections of Aviation Science Students}

\author{
Stephen Belt and Leah Sweetman
}

It can be a challenge to implement servicelearning activities within STEM-related professional disciplines that do not directly connect to issues facing the community. To be effective, the activity must be a collaborative effort, address a real need, and support the courselevel learning objectives. Growing out of an established volunteer program at a local elementary school, two potential opportunities to make this connection were identified within upper division courses in Aviation Science: (1) Fundamentals of Flight Instruction for professional pilot majors and (2) Senior Seminar for aviation management majors. Presented in this article are the retrospective perceptions of aviation science undergraduate students who participated in an aviation elective program at a local elementary school. Aviation science students practiced their teaching craft and honed their leadership skills in a real setting with actual students. They were encouraged by the children's responses and were hopeful that they might have helped to inspire future achievements. Based on the findings of this study, the authors offer recommendations.

Keywords: aviation science, flight instructor, reflection, service-learning, STEM

\section{El aprendizaje de servicio en una disciplina profesional: Explorando reflexiones de estudiantes de la ciencia de la aviación}

\author{
Stephen Belt y Leah Sweetman
}

La implementación de las actividades relacionadas al aprendizaje de servicio dentro de las disciplinas profesionales CTIM (ciencia, tecnología, ingeniería y matemáticas) puede resultar desafiante si no conecta claramente con asuntos comunitarios. Para ser efectiva, la actividad debe ser un esfuerzo colaborativo, ocupa de una necesidad real, y apoya los objetivos pedagógicos del curso. Surgidas de un programa de voluntariado establecido en una escuela primaria local, dos oportunidades potenciales para hacer esta conexión fueron identificadas dentro de los cursos de alta división en la ciencia de la aviación: "Los fundamentos de la instrucción del vuelo" para los estudiantes de piloto profesional y "Seminario del último año" para estudiantes de gestión de la aviación. Aquí se presentan las percepciones retrospectivas de los estudiantes universitarios de la ciencia de la aviación quienes participaron en un programo electivo en una escuela primaria local. Los estudiantes practicaron sus habilidades didácticas y mejoraron sus habilidades de liderazgo en un contexto real con estudiantes reales. Ellos se encontraron motivados por las respuestas de los niños y optimistas al pensar que ellos mismos tal vez hubieran ayudado a inspirar futuros logros.

Palabras clave: la ciencia de la aviación, el aprendizaje de servicio, reflexión, CTIM

Editors' Note: English-to-Spanish translation by Megan J. Myers

Department of World Languages and Cultures

Iowa State University, USA 
Service-learning is well established in the social sciences and in disciplines in which clinical experience represents an important part of the learning process (Hoxmeier \& Lenk, 2003; Kenworthy-U'Ren, 2000). However, it can be a challenge to implement service-learning activities within applied science or professional STEM (science, technology, engineering, and mathematics) disciplines that do not directly connect to issues facing the community. For example, perceptions that service-learning lacks rigor and takes too much time have hindered the growth of service-learning in the sciences (Bernot et al., 2017; Brubaker \& Ostroff, 2006; Hamerlinck, 2013; Sherman \& MacDonald, 2009). In discipline-based servicelearning courses, the link between course content and community experiences must be explicit (Heffernan, 2001). To be effective, the activity must be a collaborative effort, address a real need, and support the course-level learning objectives.

Furthermore, a focus on critical service-learning challenges the participants to form relationships based on connection and to promote a more-just society. According to Mitchell (2008), "Critical service-learning programs encourage students to see themselves as agents of social change and use the experience of service to address and respond to injustice in communities" (p. 51). Thus, in STEM disciplines such as aviation science, there is a limited range of possible experiences that can both support course objectives and provide meaningful service.

Growing out of an established volunteer opportunity at a local elementary school, potential opportunities to make this connection were identified within two upper division courses in Aviation Science: (1) Fundamentals of Flight Instruction for professional pilot majors and (2) Senior Seminar for management majors. The specific learning objectives that relate to each concentration are different, but the inclusion of a service-learning component was intended to provide an opportunity for students in either major to perceive some of the barriers to inclusion that children in an underserved population face. The desired learning outcome, in this sense, was for the students to grapple with and develop a greater understanding of the complexities that surround and underpin the issue of diversity in aviation. In these ways, the addition of service-learning sought to provide a learning component for the undergraduates that would foster greater cultural humility and cultural competence (Greene-Moton \& Minkler, 2020).

As Schultz (2007) pointed out, social justice cannot activate itself. The deep divide caused by racism and the lack of diversity in an industry will not be corrected without concerted efforts by many different stakeholders. If professional programs can utilize critical service-learning approaches that directly engage the discipline, they may serve to help students better understand and critique systems of racism and white privilege. Entering the professional world, those students will be better equipped to take action and effect real, systemic change.

Although there are a number of ways to assess the value of such efforts, presented in this article are the retrospective perceptions of aviation science undergraduate students who participated in offering an aviation elective at a public elementary school. The purpose of this qualitative study was to explore the value and effect of incorporating a service-learning experience into upper division aviation science courses through the lasting impressions of the undergraduates who participated. Additionally, the researchers were interested in discovering how the recollections and perspectives of the participants might reflect qualities of empathy and understanding in support of developing "agents of social change" (Mitchell, 2008, p. 51), with respect to their chosen profession.

\section{Service-Learning in STEM Disciplines}

Research specifically dealing with service-learning in aviation education is insufficient to provide a context for the present study. However, because aviation science shares many traits with other STEM disciplines, service-learning in one such discipline will be described in this section. Engineering as a discipline has both adopted and studied the use of service-learning within the more technical aspects of the curriculum (ASEE [American Society for Engineering Education], n.d.). In 1995, Purdue University launched Engineering Projects in Community Service Program (EPICS), the first program to formally integrate service-learning into an engineering curriculum (Coyle et al., 1997). Ten years later, Coyle et al. (2005) found that, in addition to gaining experience working on teams and developing their technical engineering skills, the 
EPICS program students reported learning other professional skills like communication and project planning. Students had often participated in community service in the past, but EPICS was the first opportunity to combine community service with engineering. Students consistently reported that, through the program, they developed an awareness of the community and the customer in the service project.

Since the inauguration of the EPICS program, service-learning has emerged as a significant pedagogical tool in engineering education (Wang et al., 2018). For example, Fitzallen and Brown (2017) found that, through a STEM outreach program in a local school, university student participants exhibited the development of personal and social responsibility skills. Students in the STEM outreach program ran handson activities at science expos, delivered educational programs in schools and on campus, and conducted professional learning for teachers to assist with the development of content knowledge. The development of personal and social responsibility skills was evidenced in the way in which the teams strived to meet the learning needs of the students, provide engaging experiences, support one another, and continue to be involved in the program.

In another study, Abu-Mulaweh et al. (2020) found, through the analysis of written reflections, that human interaction in engineering service-learning projects led students to express components of empathy. The most common empathy construct was self-awareness and an awareness of others. A few students came close to perspective taking, where the students imagine themselves in another person's position. This follows the study by Wang et al. (2018), who found that spending time and interacting with local people in the community was one of the mechanisms that was instrumental in the development of empathy during the service-learning experience.

Rupnow et al. (2018) conducted interviews with civil engineering students who participated in a variety of service-learning activities. The researchers found that the learning positively connected engineering identity with service. Additionally, the experience supported movement toward long-term pursuit of service activity and engineering educational outcomes related to both technical skill and personal development. Finally, service-learning reinforced educational outcomes by helping to contextualize the engineering profession within broader societal concerns and promote civic-minded, socially responsive professional practice.

Most recently, in a study on service-learning in aerospace engineering, Pippin and Chierichetti (2021) found that participants learned the value of inspiring children to become engineers - in particular, students belonging to minority groups. The service-learning project allowed the students to develop an activity that related to aerospace structures. They engaged in the activities with children in after-school programs. The experiences reinforced their own understanding of course concepts while providing an opportunity to teach children. Participants also learned the importance of providing children with good role models and valued that they were able to acquire patience through their teaching.

\section{Background}

\section{Institutional Context}

Saint Louis University (SLU) is a Catholic Jesuit institution with campuses in St. Louis, Missouri, and Madrid, Spain. Founded in 1818, SLU was the first university west of the Mississippi River. The university is home to approximately 7,800 undergraduates and 4,500 graduate students (including medical and law students) from all 50 states and more than 70 countries. The St. Louis campus is located in the Midtown neighborhood, within the city's arts district, and five minutes from the Gateway Arch on the Mississippi Riverfront. The mission of SLU is the pursuit of truth for the greater glory of God and for the service of humanity. In support of the mission, SLU "fosters programs that link University resources to local, national and international communities in collaborative efforts to alleviate ignorance, poverty, injustice and hunger; extend compassionate care to the ill and needy; and maintain and improve the quality of life for all persons" (Saint Louis University, n.d.).

In 2009, SLU launched the Center for Service and Community Engagement (CSCE)-recently renamed the Center for Social Action (CSA) - to bring together students, faculty, staff, and community partners 
through service, community-based learning, and research. The CSA scaffolds programs to encourage personal and social responsibility by transforming student volunteers into effective servant leaders and advocates of social justice. The CSA's goals are threefold: (1) Serve by connecting students, faculty, staff, and alumni to volunteer opportunities in the community, both locally and globally; (2) Learn by promoting community-based scholarship through campus-wide service-learning efforts and university-community research partnerships; and (3) Engage by encouraging personal and social responsibility in SLU volunteers and challenging them to become effective servant leaders and advocates of social justice.

SLU's commitment to community engagement and service is a widely recognized strength of the institution. Each year, students, faculty, and staff contribute over one million hours of service work to the greater St. Louis community. Such a culture follows naturally from SLU's Jesuit mission and identity. Furthermore, SLU's annual Student Survey on Service consistently shows that nearly $80 \%$ of enrolled students engage in volunteerism during their time at SLU, as compared to the national average of $26 \%$ for college students (Corporation for National and Community Service, 2015). As an institution, SLU has received many community engagement honors, including several Presidential Honor Roll recognitions by the Corporation for National and Community Service, a 2015 Community Engagement Classification by the Carnegie Foundation, and a Number 1 ranking for community service by the Princeton Review (Franek et al., 2018).

Although students regularly engage in service to the community, most of it is cocurricular in nature. They serve through student organizations or make an individual commitment to a community partner. Less than $10 \%$ of students indicate that their service is part of a course at SLU. In order to better support faculty who are interested in developing service-learning courses, CSA staff serve as consultants, helping faculty to integrate service-learning activities into their course syllabus, identify community partners, and design service-learning assignments that are assessable. Simultaneously, the CSA works with over 500 community organizations to learn about their needs and to facilitate partnerships with faculty and students. Finally, the CSA helps to prepare students to enter local communities and critically reflect on their service experiences in relation to their course learning goals. Whereas there are many definitions of service-learning, SLU, as a member institution, uses the Campus Compact (2019) description as a guide: "Service-learning incorporates community work into the curriculum, giving students real-world learning experiences that enhance their academic learning while providing a tangible benefit for the community."

\section{Community-Engaged Aviation Activity}

A community-engaged aviation activity between the Department of Aviation Science at SLU and Farragut Elementary School was born as a response to a call that emanated from a faculty member's relationship with the school. Through a series of encounters at various community meetings and events that spanned more than a year, the professor, who is also a member of this research team, became acquainted with the administration. He was invited to participate in a series of meetings where the administration and community stakeholders considered the future of the school and how it might continue to improve. According to the principal, Patricia Cox, as a result of this process, the school adopted a "collegiate approach" and implemented a series of Friday afternoon electives they named Farragut University (Cox, 2019). This effort was intended to present "a world of "what-ifs"" and enable the children to "see beyond the horizon" and consider a variety of future possibilities. Regarding the community partners involved in this program, Cox stated, "[They] do the heavy lifting in the classrooms, sharing their expertise." Through these activities, she continued, the children were "gaining a clearer understanding of how what they are learning connects to the real world."

The aviation elective sought to respond to this call in three ways: (1) introduce the field of aviation as an aspirational career option, (2) consider aviation within an African American context by exploring the rich and long-standing African American history in aviation, and (3) investigate age-appropriate science topics as they apply to aviation. Aviation was a topic well suited to provide a nontraditional approach to STEM education and promote academic persistence while offering the children a notion of aviation as a possible future profession in a field that is historically homogenous but faces unprecedented labor demands. 
The use of PC-based flight simulation devices presented the children with a "real-world" experience of learning how to become a pilot. The simulators also provided a learning environment where the children could explore and apply abstract concepts such Newton's laws of motion and Bernoulli's principle.

For the undergraduate students, the program began as a volunteer activity. During the fall offerings, aviation science majors were invited to participate. The open invitation attracted a sufficient number of volunteers to complete the fall programs. Thus, the program was not specifically part of an undergraduate aviation course at the start. Furthermore, the aviation science program comprised two concentrations, professional pilot and aviation management, and the relevant learning objectives of each concentration were different. For aviation management majors, the learning outcomes were less directly tied to the content or academic skill of a specific course, and the learning value of participation could be more appropriately described as professional skill development (Lim, 2018).

During the spring semester, the elementary school elective was formally integrated as a service-learning component within an upper-level Fundamentals of Flight Instruction course. This course provided a comprehensive introduction to the educational theory and methods that underpin the flight instruction process and established the minimum criteria for certification as a flight instructor (Federal Aviation Administration [FAA], 2008, 2018). At the conclusion of the course, students are expected to be able to

1. Define and discuss the fundamentals of instruction

2. Demonstrate effective use of the fundamentals of instruction in 1:1 and group settings

3. Explain their personal philosophy of teaching based on recognized educational theory

4. Develop lesson plans that are centered on student performance

5. Develop and utilize outcomes-based lesson objectives

6. Evaluate instructional effectiveness

7. Demonstrate critical-thinking skills

8. Complete the appropriate FAA knowledge exams

9. Demonstrate proficiency with material related to the FAA Flight Instructor's Airplane Practical Test Standards

For these aviation students, the activities related to offering the elective-preparing lessons, entering the classroom and presenting those lessons, engaging the elementary school children, providing flight instruction on PC-based desktop flight simulating devices, and evaluating performance-were all directly related to the content and objectives of the university course. Furthermore, the rich context of the project offered a novel way for the aspiring flight instructors to engage with the course material. Traditionally, a common practice with instructor candidates is to have them role-play with their classmates. Although such activity helps them to make the transition from student to instructor, as Crow and colleagues (2011) noted, the benefits of the practice are of limited value and are potentially adverse. It was therefore anticipated that the service-learning experience would provide a better learning experience for the undergraduates.

The undergraduates had multiple opportunities to reflect upon their experiences. The small class size made it easy to have in-class discussions. Similarly, traveling to and from the elementary school site provided an opportunity for informal discussions among the college students.

Considering the broader community, this approach presented an opportunity to support increased diversity and access within the profession at a time when the industry was looking for ways to expand the pool of qualified applicants. The aviation industry had entered a 10- to 20 -year period when hiring pilots and mechanics would likely outpace the number of qualified candidates (Boeing, 2019), and this had the industry keenly interested in expanding the applicant pool. As an example, the PC-based flight simulators used in this aviation elective were provided through a flight education grant from American Airlines. However, while the desire to increase recruitment may have supported greater diversity, it was unlikely that it would automatically lead to successful outcomes without moving to identify, understand, and address the issues that prevented inclusion. According to Ison (2009):

While the trends in the participation rates by minorities within aviation higher education are positive, overall participation rates of minorities in aviation are still unimpressive. It is therefore 
more critical than ever that efforts are put forth to encourage and support minorities entering and completing aviation higher education programs to help boost levels of these individuals among the aviation profession (p. 61).

Related to this dynamic is the local reality that a large portion of the aviation industry is physically adjacent to underrepresented communities and yet remains inaccessible, even in theory. The Ville neighborhood within which Farragut is located is a prime example of this reality. Furthermore, a legacy of exclusionary policies and practices has created a St. Louis so thoroughly separated that its divides are nationally known. Delmar Avenue functions as a dividing line between commercial investment and neglect, white and Black residents, and individual wealth and poverty. After the BBC (2012) made a short documentary of the significance of the Delmar Divide, the term caught on beyond the greater St. Louis area. The Ville neighborhood is north of the Divide, about 1.5 miles north of SLU's main campus. For nearly 100 years, it was a center of African American culture and home to many Black professionals, businesses, and entertainers (4the Ville, n.d.). Once a thriving community, the Ville is now one of the more distressed areas of St. Louis (Sweetman et al., 2020; Sweetman \& Sokol, 2016).

Although there are ample opportunities for engaged service north of Delmar, relationships that bridge the divide often seem focused on difference. A focus on critical service-learning challenges us to bridge that divide and form relationships based on connection (Mitchell, 2008). This type of engaged service north of Delmar goes back more than 20 years for the researchers (Belt \& Bollock, 2020; Sweetman \& Sokol, 2016). This allows for developing more authentic relationships, and the longer-term relationships provided continuity to avoid the student turnover typical in traditional service-learning courses (Brown, 2001).

\section{Method}

The focus of this study was a diverse group of 10 university undergraduates, all majoring in aviation, who participated in offering an aviation enrichment elective at a local public elementary school. All study participants were over the age of 18 and were in the third or fourth year of the four-year bachelor's degree program. Eight students participated through the Fundamentals of Flight Instruction service-learning course while the remaining two were aviation management majors who volunteered. Two male participants were BIPOC (Black, Indigenous, People of Color), one African American, and one Asian. Eight participants were white, two females and six males. The university participants were supervised by school staff. The researchers did not collect data from the elementary school children or staff. All research was conducted with the approval of the SLU Institutional Review Board.

The aviation program was established upon invitation from the elementary school to be offered twice a year and had been offered five times at the time of data collection. Each session attracted approximately 15 elementary school children. The children were in the 4th and 5th grades; signed up voluntarily for the class; and represented a racially segregated, lower income, predominantly African American neighborhood. All children who participated were African American. Even though data from the elementary school children were not collected, the typical age of children in these grades ranged from 9 to 11 years.

\section{Data Collection}

Data for this study were collected through one-on-one, semi-structured interviews. Each undergraduate was interviewed by a member of the research team. Interviews were conducted between 2 and 18 months after the student had participated in the program. The interviews were conducted by telephone and were digitally recorded with the participants' consent. Each interview lasted approximately 20 minutes. Interview questions focused on the aviation science students' motivations for getting involved; the impact of the program had on the college students as well as the children; their interest in aviation and their perceptions of higher educational opportunities for the youth. For example, two of the questions asked were as follows: "What was the most powerful experience for you?" and "What are your perceptions of the barriers or assets related to the kids going to college?" Specific follow-up questions were asked, when considered appropriate, to clarify responses or to elicit additional insight. Participants were able to speak freely, and at 
the close of each interview, the interviewer asked if there was anything else they wished to share. Transcriptions of each interview were used for analysis.

Creswell and Poth (2018) pointed out that one challenge of a qualitative study is that the researcher must decide how their personal experiences will be introduced into the study. As noted above, the researchers involved in this project each possessed more than 20 years of experience in the Ville neighborhood. One research team member was the course instructor who developed and supervised the service-learning experience. The other team member. who was not directly involved in the experience, conducted all interviews and performed the initial data analysis.

\section{Data Analysis}

Analysis followed what Creswell and Poth (2018) described as the Data Analysis Spiral and included immersive engagement, multiple open coding, axial coding, and dialogic engagement. To protect the narrative flow of the interviews, the researchers were careful to not fragment the data. A process of immersive engagement and memoing provided a general sense of the information and shaped the open, multiple coding process (Ravitch \& Carl, 2016). The two researchers independently reviewed the data and then compared their findings. Where they disagreed, the team referred to the original recordings for clarification. In this way, they bracketed their respective experiences and sought to maintain fidelity to the voices of the participants and to refrain from interjecting their personal views. The researchers then adopted an axial coding process to identify patterns that connected the data from the interviews (Miles et al., 2020). The process was ongoing; it involved continual reflection on the data, as suggested by Rossman and Rallis (2012). The researchers further analyzed the codes to identify the lessons learned (Lincoln \& Guba, 1985). The researchers were not mere mouthpieces for the interview subjects (Bryman, 2012); through the data analysis, the findings became significant in their own right.

\section{Findings}

Three themes emerged from the analysis: (1) teaching, (2) connectedness, and (3) barriers. The first theme directly connected the experience to course-level objectives for the flight instructor students. The remaining two themes touched on the broader attributes of critical service-learning.

\section{Teaching}

A dominant idea amongst the university students who were part of the fundamentals of instructing course concerned the value they found in having an opportunity to gain actual experience in teaching while working with the elementary school children. In the interviews, every student from the course talked about how the service experience would help them to be a better flight instructor. As one student put it, "If you can teach elementary school kids, you can teach anybody to fly." One student, who did not look forward to working with the children, found the experience more enjoyable than they had expected. "I am not necessarily a kid person," the student remarked. "I was surprised how much I enjoyed it." More directly related to the opportunity teach, this student stated, "It was the first time that I tried to teach aviation to other people, and specifically to elementary school students. And it was a lot more fun than I realized."

Consistent with this theme was an appreciation for the realism that the experience provided. As one student remarked, "It teaches students like myself ... to teach." Referring to the method of practice teaching with the other students in the course, the student said: "It is one thing to talk with someone who knows aviation. It is another thing to talk about aviation with someone who has no clue, and you have to go through that process of breaking it down for them." Other students elaborated on the identity shift from student to teacher, which the experience provided:

For 15 years, we were the students, and we were taught to just ask the questions and not answer them, unless they were on the test. So, for the kids to be asking us for guidance was a very lifechanging moment for me, to say the least. Now it is a period of being the older one, using my experience to teach other people. That was a very powerful experience for me. 
Another student echoed this comment: "Changing from a student into somebody who is going to teach others these certain aspects of aviation; and then my first opportunity was teaching kids how to do it. I thought that was really powerful." This student also spoke in terms of the confidence the experience helped them to gain: "Being able to take those baby steps forward to teach people gave me a lot of inspiration for the future in teaching other people." This participant summed the experience up in this way: "I had the opportunity to be in a situation where I was up in front of a class, talking about something I love. It was a great experience."

As previously noted, two of the participants volunteered for the activity and were not part of the flight instructor course. One of these participants spoke of how the experience helped to build their confidence. Before the experience, they "had trouble with public speaking." Reflecting on the experience, they shared, "Nothing gets you over that fear than teaching kids. Be prepared. Give a concept well. Have a beginning, middle, end. Expect some weird questions." This student went on to describe the significance of the experience in terms of leadership development and becoming a professional pilot:

Helped with flying, especially when I went into commercial [pilot training]. They want you to take that leadership role. You are going to be working for hire. You are going to have to take the lead. It definitely helped with those skills. [Before], I was quiet as a mouse. Helped with those skills.

A few participants expressed the value of the experience directly in terms of doing service: "I felt that I was not involved enough in the community. ... This came up ... [and] was a way to be active and volunteer in the community." The other volunteer who was not a part of the instructor course expressed gratitude and a desire to give back: "I wanted to teach aviation. I wanted to give back. I owed SLU because that is where I got into aviation, and I can give the experience to others."

One student talked about the benefits of teaching as a group: "Sometimes we would stumble trying to get the kids to understand the topic. The other classmates, their experiences and their perspectives, could meet the kids where they were, pick up [and] fill in." They spoke of watching and working with their classmates, recognizing one another's talents, and valuing teamwork. "Some of us just have better styles, were better at relating to kids," they said. "It was really neat to see that. One SLU student, in particular, could really explain and break down a topic in a way that the kids could understand."

\section{Connectedness}

Beyond the practical application of their coursework, a second theme emerged in terms of the value of the service-learning exercise for the university students. Through their experiences, the undergraduates appeared to connect with the children. During the interviews, they easily transitioned from discussing the usefulness of applying course material in a practical setting to emphasizing the impact the experience might have had for the elementary school students. The interview responses revealed a level of concern for the children as the university students appeared to be keenly aware of the significance of the program from the perspective of the children.

All participants recognized the interest that the children had in the aviation program. "You can see it in their eyes," one participant remarked. "They would get up, walk away, and turn back; and you could see that they were in awe of what they just did." The participants shared that they thought the children enjoyed meeting pilots and learning about history, and they were especially excited with active learning components. As one participant put it, "It was intriguing and interesting to them ... and they were pretty quick to understand things." The participant considered how the content of the aviation class related to what the children were learning in their normal classes: "They enjoyed applying things that they learned in class [during the normal school day] to aviation."

Some described the experience for the children as moving beyond recreation toward education. One participant reflected on the value of the activities:

I think the kids got something - motivation They were excited to contribute. They were engaged.

It was fun and they liked learning. Learning and excitement is a simple way to say it. I don't want to say "fun"; "fun" sounds like it is too simple. 
The challenges and rewards of working with and teaching children were evident in the responses as well. One participant spoke of the satisfaction of seeing the children begin to grasp the material. "Once an idea clicked in their head, it was pretty incredible," the participant said, "It opened up new possibilities [in the aviation field]. Having new possibilities for a career path opened up. Learning about physics, aviation, foundation was really good." Another student echoed this perspective:

The most rewarding parts were when we were making paper airplanes and you could see their faces light up when they threw them across the room. Or when they were doing simulators, and they sorta landed the plane. All they are thinking about is, "I am going to be a pilot one day!" and that is exciting.

Still another commented on helping a child work through her reticence toward the activities. "I remember one young lady that I worked with on a particular day," the student recalled. "She was just very uninterested and unenthused about it. When I asked what was wrong with her, she was just, 'Oh, I don't know.' I was like ok." The student did not press the issue but continued the day's activities. Eventually, the child began to engage. "As we kept coming and getting more stuff, she enjoyed it more as she understood more, possibly because she understood more what we were doing." The student stressed this aspect of their insight: "She was probably disinterested because she didn't understand why we were doing certain things or what we were doing. But as time went on, she started understanding; so she started to enjoy it a little more." For one participant, a fuller realization of the depth of the engagement came on the last day. Th participant recalled:

They seemed to enjoy it. I know the last day they were upset that it was the last day. They were not happy about that. They were hoping that we were going to keep coming back every Friday. That is where we really realized, oh wow, they enjoyed having us and hanging around us.

Finally, one university student imagined that the children were so excited by the activities that they would bring their experiences home. "I am sure they went home plenty of times and talked to their parents about their day," the student said. Then the student explained why they thought this would happen in terms of the children's agency: "They were able to choose something. They enjoyed the learning, asked for information. And could do cool things in aviation, like the simulator." This participant proceeded to reflect in light of their own childhood: "When I grew up, I didn't have any of these programs, and I wish that I did. What kid doesn't dream about being a pilot, for a fleeting moment, as they hear the sound of the engines above them?"

\section{Barriers}

The university students were asked to imagine the barriers that the elementary school children might face in terms of going to college. Several participants recognized that the cost of higher education, particularly aviation programs, could be a barrier for the youth and their families. Although fee structures vary, the additional fees associated with the flight training necessary to become a professional pilot were extreme and could range from $\$ 50,000$ to more than $\$ 80,000$. Although scholarship and other financial aid exist, this reality is a primary consideration for all aspiring pilots. One participant put it rather succinctly:

Without some backing or financial support, an aviation college would be hard to do. I hate to say it, but it is a barrier. Aviation college is something different. On top of tuition, you have to pay flight fees, tests, etc. They get pricey. Without financial backing, it will be a barrier. It is a barrier in aviation.

Beyond the expense, another common theme regarding barriers had to do with access to aviation and the moral support necessary to be successful in the industry, particularly as a pilot. Most participants noted that aviation is a field where oftentimes people become pilots because they have a connection to the industry, such as a family member or close friend who is a pilot. The previously mentioned student continued, "Also, not a lot of people know about [the field of aviation]." One participant reflected on this reality within their own experience: 
I am the first pilot in my family It is all learn as I go. My girlfriend is a pilot, and her parents are pilots. ... Being the first pilot has its struggles. ... [You] need exposure if no one in your family is a pilot.

"I am sure there are financial and social barriers that would prevent them from attending college," another student reflected. However, the greater concern seemed to be this notion of support:

I do strongly believe that having a family member, friend, or mentor that can show them that it is attainable and can act as a role model who can show them they could further their education in that manner.

This student was quick to point out that these types of programs should continue to provide opportunities for the youth and to help maintain the connections to the educational path and career pipeline. "It was important that we were there," the student reflected, "Maybe [we] started a few of them on a path. SLU students represented the career path, the field. The program made it tangible for them." This student imagined the possibility of bringing the children to the airport for a field trip. "We talked about it, that it would be cool if we could actually take the kids to the airport and maybe even take them up in an airplane and show them."

This sentiment was echoed in a number of ways. One was in terms of the value of having participated in the program. "Was it worth it?" this university student asked, then reflected:

I think aviation is still a very niche community. Not a lot of people understand how to join, and I think there are a lot of opportunities available to join the aviation community. So, introducing this new world to them, maybe they will have an opportunity to pursue it in the future, but at least they can see what it is like. They were able to explore their horizons. Whether they pursue aviation, they at least gave it a shot.

Another considered providing greater access to aviation:

We are going into their world, right? And we talk about this other world that they have no idea even exists. And so, to actually, physically take them to this one and say, "Hey, you know this is what you want to do, this is where you are going to be working, what you get to do every day," and I thought getting them out a couple of times on a field trip would be a good thing.

The participant then recommended an expansion of the program: "I would think for the Farragut project to be effective, it would almost have to be longer. ... Hopefully, we kind of crack that a little bit. Hopefully." Certainly, there was a willingness and a desire to share their passion for aviation. As another participant noted, "Being able to open up the possibilities and teach them about aviation. I think all those pilots love talking about aviation, and we could do it all day."

Barriers in terms of broader societal issues came up sporadically and in different ways. One participant began to explore the topic of race and socioeconomics: "Those barriers are definitely an issue and are more deep-rooted than just being able to go to college or wanting to go to college. ... It is deep rooted in the policies and everything else with the country and what not." The same participant went on to reflect on his own experience and the example it might be for the elementary school children:

And for them just to see me, a Black man in today's time, who is a pilot and who was studying to be an instructor at the time, that is good representation of the Black community inside aviation.... It was just good representation of us, and a role model, I guess. To let them know that this is possible, this is an avenue for us, as a people, for really anybody, but for us as a people because there are not too many Black pilots.... So, it is good representation so that they can see that and understand that it is possible for them.

Another student specifically mentioned the enthusiasm and ability of the girls in the group: "They asked questions, picked it up fast. They were most eager to get into the simulator. That was the most memorable part.". The participant then reflected on the lack of gender diversity in aviation: 
We hear all the time that aviation is male-dominant field. We need more women. I think women do want to do this. My mother is a pilot. I see it. Those girls were on top of it. They were the ones participating. That was exciting to see from my standpoint in this male field.

One student reflected on potential barriers with regard to cultural expectations and aspirations:

I feel that barriers are really about what kind of high school you went to. If all of your friends are going to college, then the barriers are not about if you are going to college, but rather where you are going to college."

They then reflected on their experience with the program and how local cultural barriers might be active. "I think for that kind of community, college is really dependent on how many people are going. The question of if becomes the bigger reality. That is the biggest barrier for them."

Another student was less optimistic. "I wish there was more value in them actually doing aviation after that. There was more value in them enjoying their Friday and learning more about the industry," they said. "A lot of people around them are not going to college. And maybe their parents didn't go to college, so it isn't expected that they would go to college. Could be biggest obstacle." Yet another participant, while noting that "there will be a lot of barriers," pointed to the efforts evident around the school:

I think Farragut does a great job encouraging students, that college is a possibility. There are posters all over with different universities with different information. There are a lot of difficulties, especially in that neighborhood where there is a lot of poverty and maybe not the best home life. But I think the school does a great job encouraging the kids that higher education is something you can obtain.

None of the students mentioned academic challenges or college readiness as factors that could limit their opportunities for aviation or success in college overall. Rather, many returned to a notion of an overriding passion for the profession. As one participant reflected on the financial and familial barriers, they spoke of such a desire: "If you can get through that initial barrier with cost, there is not much holding you back besides your personal desire to become a pilot." Another participant echoed this, expressing confidence in the children's ability:

The kids in my group for the most part really do like what we do. They like the learning of it; they like contributing; they really, really want to participate. So, I think they have the desire, motivation, and energy to go to college.

\section{Discussion}

The themes that emerged from the analysis of the data have each expanded our understanding of how service-learning may contribute to the education of aviation majors. The university students unmistakably valued the opportunity to explore and apply core concepts of the course to the service-learning component. It was clear that the students cared about and benefited from the practical and directly applicable experience they gained from working with the elementary school children. It was also clear that they began to identify with the children and empathized with the challenges they faced. For the students preparing to become flight instructors, working with the children offered an environment that facilitated their transition from students to teachers. The students were suitably challenged in a nonthreatening environment to provide accurate technical information and a quality learning experience. This outcome was encouraging as it indicated a learning component that met a number of the course objectives and thus met one of the primary objectives of service-learning. This should be closely monitored, in terms of both future course offerings and follow-up with student participants as they become certified and gain experience as flight instructors.

Given the nature of the fundamentals of instructing course, we anticipated that the experience would support the course objectives. Beyond the benefit of practice teaching, students reported developing leadership skills as they connected their academic discipline with the hands-on experience of relating with the community in response to a real need. For aviation science students majoring in management, this 
finding lends support for considering ways to incorporate service-learning into an appropriate upper-level course that focuses on leadership and management.

Service-learning courses provide opportunities for personal growth, including identity development and cultural understanding. Previous studies reported evidence of social awareness, responsibility, and developing empathy (Abu-Mulaweh et al., 2020; Fitzallen \& Brown, 2017; Wang et al., 2018). In the present study, it was clear from the responses that the students were connected to the children. They developed relationships, were attentive to how the children received the activities, and thought about how the experience may have helped them. The students thought, or at least hoped, the effort was of value to the children. As such, some measure of cultural competence was evident in their reflections and indicated that the program successfully introduced the students to some of the injustices facing underrepresented children who may otherwise aspire to enter professional aviation. The responses further suggested that the participants had become advocates for the children with whom they worked. They recognized many of the barriers the children faced, but they believed in the abilities of the elementary school children and their potential for success.

\section{Limitations and Recommendations}

What remained unclear was the degree to which this empathy and understanding developed as a direct result of the program. This reflects a limitation of the study. The students may have arrived with similar experiences and inclinations. They may have been active in other courses or other aspects of campus life that helped to develop their cultural competence. They may have been attracted to SLU, in part, precisely because of its commitment to service.

Additional research is necessary. Future studies could help us better understand the predispositions of the student body and how their perceptions change as a result of the service experience would help to clarify the impact of the activity and inform programmatic adjustments to better serve both the university students and the elementary school children.

Another limitation of the study was the absence of the children's perspective and that of their teachers. Indeed, it is impossible to gauge the impact of the service without their voices. Research that includes these perspectives will help to illuminate the value and the shortcomings of the program, not only in terms of the service provided but the accuracy of the perceptions of the university students as well (see, e.g., Belt \& Bollock, 2020). In the meantime, there are a few indications of the success of the broader program within which the aviation elective resides. According to Cox (2019), students in the program "are raving about what they call the "college experience." "Furthermore, as Cox added, since the implementation of Farragut University, "student attendance has increased and there has been a sharp decrease in off-task behavior."

It was likewise difficult to gauge what impact such an experience might have on future trends in diversity within the aviation profession-whether the participants will become agents of change in this regard. Even though the findings of the present study were promising and provided support for hope, it will be some time before the effects of such experiences have any discernable impact on hiring trends. Furthermore, the small number of university students considered in this study does not approach a representative sample. However, based on the findings, it is recommended that a follow-up study be

conducted with the same university students in five to 10 years' time to investigate the long-term effect of the experience. In the meantime, the findings support continued development and application of servicelearning within aviation and other technical disciplines.

\section{Postscript Regarding COVID-19}

As a postscript to the study, the service-learning activity was scheduled to be offered again during the second half of the spring 2020 semester in both the Fundamentals of Flight Instruction and Senior Seminar courses. The instructor was developing relationships with other schools in order to expand the program when all such activity was curtailed due to the COVID-19 pandemic. The week before the fundamentals of instructing course was to begin at Farragut, the elementary school cancelled all programs with outside visitors. A few days later, the city-wide shutdown due to COVID-19 followed. All university courses moved 
online, and the remainder of the semester was in a virtual classroom. Practice teaching was accomplished by returning to the common practice of pairing the students up and having them role-play as student and instructor for each other. The students completed the course and performed well; nevertheless, some shared that they were disappointed that they did not get to "do real teaching" at the elementary school. We are encouraged that, in this short time offering a formal service-learning program within aviation science, the students were looking forward to the activity. Through its absence, they recognized the benefit of the service-learning component.

\section{Conclusion}

Critical service-learning practitioners strive to develop authentic relationships among students, faculty, and community partners in an effort to promote a more just society (Mitchell, 2008). The aviation servicelearning program at Farragut Elementary sought to engage this objective in a way that was directly tied to the technical education and professional aspirations of SLU aviation science majors. Creating viable service-learning projects with community partners takes time. There needs to be a commitment and an understanding of the partners' point of view, including their needs and interests. Through strong collaboration with Farragut's administration and seeking to expand the horizons of the school children, the university endeavored to offer the kind of program that would facilitate learning and provide meaningful service.

As revealed in their own words, the students who participated in this program benefited from the experience by having an opportunity to practice their teaching craft and hone their leadership skills in a real setting with actual students. They connected with the elementary school children and were able to share their passion for flight. They were encouraged by the children's responses and were hopeful that they might have helped, in some small way, to inspire future achievements, perhaps even as part of the next generation of aviators. The university students believed in the elementary school children's ability to succeed, and they imagined how they, or other university students like them, might be of greater service to nurture and support the ambitions of children such as those whom they interacted. The degree to which these aspiring professionals may serve as agents of change within the industry remains to be seen.

Additional research is needed to more fully understand and respond to challenges related to servicelearning within STEM education disciplines such as aviation. The intermediate findings suggest the need to continue and develop this effort and to conduct additional research into its effectiveness. For now, the value of a service-learning component is recognized. Service-learning contributed substantially to learning as part of both courses and allowed the students to provide a meaningful technical service to the community. Finally, it represents a step, however small, toward a world of professional aviation that is more equitable and just.

\section{References}

4theville (n.d.). About the Ville. http://www.4theville.org/about-the-ville/

Abu-Mulaweh, N., Oakes, W. C., \& Leidig P. E. (2020). Empathy in a service-learning design course. ASEE Peer. https://peer.asee.org/34524

ASEE [American Society for Engineering Education]. (n.d.). ASEE Community Engagement Division. Retrieved March 22, 2021, from https://sites.asee.org/ced/about/

BBC (Producer). (2012). Crossing a St. Louis street that divides communities. Retrieved March 12, 2021, from https://www.bbc.com/news/av/magazine-17361995/crossing-a-st-louis-street-that-dividescommunities 
14 | International Journal of Research on Service-Learning and Community Engagement

Belt, S. M., \& Bollock, N. K. (2020). Assessing an aviation out-of-school time program: A collective case study. Collegiate Aviation Review International, 38(1), 106-121. http://ojs.library.okstate.edu/osu/index.php/CARI/article/view/7961/7384

Bernot, K. M., Kulesza, A. E., \& Ridgway, J. S. (2017). Service learning as inquiry in an undergraduate science course. The American Biology Teacher, 79(5), 393-400. https://doi.org/10.1525/abt.2017.79.5.393

Boeing. (2019). The 2019 Boeing pilot and technician outlook. Retrieved April 1, 2021, from https://www.boeing.com/commercial/market/pilot-technician-outlook/\#/overview

Brown, D. M. (2001). Pulling it together: A method for developing service-learning community partnerships based in critical pedagogy. Corporation for National Service.

Brubaker, D. C., \& Ostroff, J. H. (2006). Life, learning, and community: Concepts and models for service-learning in biology. Stylus.

Bryman, A. (2012). Social research methods (4th ed.). Oxford University Press.

Campus Compact. (2019). Service-learning. Retrieved August 1, 2021, from https://compact.org/initiatives/service-learning/

Corporation for National and Community Service. (2015). Volunteering and civic life in America. https://www.nationalservice.gov/vcla/demographic/collegestudents

Coyle, E. J., Jamieson, L. H., \& Oakes, W. (2005). EPICS: Engineering projects in community service. International Journal of Engineering Education, 21(1), 139-150. https://www.ijee.ie/articles/Vol21-1/IJEE1549.pdf

Coyle, E. J., Jameison, L. H., \& Sommers, L. S. (1997). EPICS: A model for integrating service-learning into the engineering curriculum. Michigan Journal of Community Service Learning, 4(1). 81-89. http://hdl.handle.net/2027/spo.3239521.0004.109

Cox, P. (2019, June 5). Community partners making a difference at Farragut Elementary. The St. Louis American. http://www.stlamerican.com/news/columnists/guest_columnists/community-partnersmaking-a-difference-at-farragut-elementary/article a2b3eb18-87f1-11e9-87235ba9eddc3390.html

Creswell, J. W., \& Poth, C. N. (2018). Qualitative inquiry and research design: Choosing among five approaches (4th ed.). SAGE Publications.

Crow, B., Niemczyk, M., Andrews, D., \& Fitzgerald, P. (2011). Role playing in flight instructor training: How effective is it? International Journal of Applied Aviation Studies, 11(1), 1-12. https://www.academy.jccbi.gov/ama-800/Summer_2011.pdf

Federal Aviation Administration (FAA). (2008). Aviation instructor's handbook.

Federal Aviation Administration (FAA). (2018). Flight instructor practical test standards for airplane.

Fitzallen, N., \& Brown, N. R. (2016). Outcomes for engineering students delivering a STEM education and outreach programme. European Journal of Engineering Education, 42(6), 632-643. https://doi.org/10.1080/03043797.2016.1210570

Franek, R., Soto, D., Koch, S., \& Aliperti, P. (2018). The best 384 colleges (2019 Ed). The Princeton Review.

Greene-Moton, E., \& Minkler, M. (2020). Cultural competence or cultural humility? Moving beyond the debate. Health Promotion Practice, 21(1), 142-145. https://doi.org/10.1177/1524839919884912 
Hamerlinck, J. (2013). Strengthening STEM education through service-learning: Highlights from the 2010 Learn and Serve America higher education STEM grants. Minnesota Campus Compact. http://mncampuscompact.org/wp-content/uploads/large/sites/30/2016/04/Strengthening-STEMthrough-SL.pdf

Heffernan, K. (2001). Fundamentals of service-learning course construction. Campus Compact.

Hoxmeier, J., \& Lenk, M. M. (2003). Service-learning in information systems courses: Community projects that make a difference. Journal of Information Systems Education, 14(1), 91-100. https://aisel.aisnet.org/jise/vol14/iss1/10

Ison, D. C. (2009). Have we made progress? Trends in minority participation in postsecondary aviation education. Collegiate Aviation Review, 27(1).

https://commons.erau.edu/ww-graduate-studies/5

Kenworthy-U'Ren, A. L. (2000). Management students as consultants: A strategy of service-learning in management education. In P. Godfrey \& E. Grasso (Eds.), Working for the common good: Concepts and models for service-learning in management (pp. 55-68). Stylus.

Lim, H. A. (2018). Service-learning: Implications for the academic, personal, and professional development of criminal justice majors. Journal of Criminal Justice Education, 29(2), 237-248. https://doi.org/10.1080/10511253.2017.1377742

Lincoln, Y. S, \& Guba, E. G. (1985). Naturalistic inquiry. SAGE Publications.

Miles, M. B., Huberman, A. M., \& Saldaña, J. (2020). Qualitative data analysis: A methods sourcebook (4th ed.). SAGE Publications.

Mitchell, T. D. (2008). Traditional vs. critical service-learning: Engaging the literature to differentiate two models. Michigan Journal of Community Service Learning, 14(2), 50-65. http://hdl.handle.net/2027/spo.3239521.0014.205

Pippin, E. D., \& Chierichetti, M. (2021). Service learning in aerospace engineering: How outreach activities are incorporated in upper division curriculum. AIAA Scitech 2021 Forum. https://doi.org/10.2514/6.2021-0353

Ravitch, S. M., \& Carl, N. M. (2016). Qualitative research: Bridging the conceptual, theoretical, and methodological. SAGE Publications.

Rossman, G. B., \& Rallis, S. F. (2012). Learning in the field : An introduction to qualitative research (3rd ed.). SAGE.

Rupnow, R., Davis, K., Johnson, R., Kirchner, E., Sharma, J., \& Talukdar, S. R. (2018). Service experiences of undergraduate engineers. International Journal for Research on Service-Learning and Community Engagement, 6(1), Article 14. https://ijrslce.scholasticahq.com/article/6893

Saint Louis University. (n.d.). Saint Louis University mission statement. https://www.slu.edu/about/catholic-jesuit-identity/mission.php

Schultz, B. D. (2007). "Not satisfied with stupid band-aids": A portrait of a justice-oriented, democratic curriculum serving a disadvantaged neighborhood. Equity \& Excellence in Education, 40(2), 166-176. https://doi.org/10.1080/10665680701218459

Sherman, A., \& MacDonald, L. (2009). Service learning experiences in university science degree courses. Innovative Higher Education, 34(4), 235-244. https://doi.org/10.1007/s10755-009-9110-7

Sweetman, L., Wassel, B., Sokol, B. W., \& Belt, S. M. (2020). Solidarity, reflection, and imagination: Exploring student formation and community engagement from a faith-based, anchor institution perspective. Metropolitan Universities, 31(3), 116-139. https://doi.org/10.18060/23994 
Sweetman, L., \& Sokol, B. W. (2016). The Ville. In T. Underwood (Ed.), Engaging with our neighbors: The practice of town-gown relations in Missiouri (pp. 93-99). Missouri Campus Compact.

Wang, L., Carroll, T. K., \& Delaine, D. A. (2018). A pilot study of the development of empathy within a service-learning trip from a qualitative perspective [Paper presentation]. 2018 ASEE Annual Conference \& Exposition, Salt Lake City, UT, USA. https://www.asee.org/public/conferences/106/papers/21505/view

\begin{abstract}
About the Authors
Stephen Belt is an associate professor in the Department of Aviation Science and the chief diversity officer of Parks College of Engineering, Aviation and Technology at Saint Louis University.

Leah Sweetman is the director of community engaged learning in the Center for Social Action at Saint Louis University.
\end{abstract}

Correspondence concerning this article should be addressed to Leah Sweetman at leah.sweetman@slu.edu. 